DOI: $10.17516 / 1997-1370-0643$

УДК 37.014 .529

\title{
The Book as an Element of Atheistic Upbringing Through the Example of the Atheist Guide Series
}

\author{
Mariia V. Kolmakova* \\ Institute of Human Philosophy \\ Herzen State Pedagogical University of Russia \\ St. Petersburg, Russian Federation
}

Received 18.04.2020, received in revised form 27.07.2020, accepted 10.08.2020

\begin{abstract}
The article concerns a series of Atheist Guide books, published by the Omsk publishing house within the period from 1983 to 1989. The books represent a developed atheist education system, which takes into account the peculiarities of the religious life in Omsk and the Omsk Region. The material of the books may be of interest to religious theorists and historians as a source of additional information about atheistic upbringing in Siberia. The authors of the series view religion as a naturally developing social phenomenon that evolves under various factors. At the same time, these texts consider religion to be a form of manifestation of the Omsk citizens' low education level. In general, the books in the series not only call for overcoming religious misconceptions but also for regarding religion as a phenomenon that plays an important role in the lives of Soviet people.
\end{abstract}

Keywords: scientific atheism, science of religion, USSR, Omsk, book series.

The research is funded by RFBR, project No. 19-311-60008.

Research area: Philosophy of Religion and Religious Studies. Art history and cultural studies.

Citation: Kolmakova, M.V. (2020). The book as an element of atheistic upbringing through the example of the atheist guide series. J. Sib. Fed. Univ. Humanit. Soc. Sci., 13(8), 1310-1316. DOI: 10.17516/19971370-0643.

\footnotetext{
(C) Siberian Federal University. All rights reserved

* Corresponding author E-mail address: kolmakovamv@yandex.ru ORCID: 0000-0002-2859-7473
} 


\section{Introduction}

In the 1980s, scientific and atheistic propaganda in Omsk was spread widely and covered almost all parts of the region. After the release of Resolutions of the Central Committee of the Communist Party of the Soviet Union (CPSU) (On Further Improvement of Ideological, Political and Educational Work (dd. April 26, 1979) and On Strengthening the Atheistic Upbringing (dd. September 22, 1981)), the pace and quality of the work increased, and Communist party officials, university and school teachers, students, journalists, and many others joined it with great diligence. Propaganda departments and the regional Scientific Atheism House widened the scope of their activities too. They hosted open lectures and discussions along with many other events.

The publication of methodical and supplementary literature for propagandists and lecturers was also one of the types of atheistic upbringing. These kinds of books always had several objectives, the primary goal being to increase the educators' public speaking proficiency and, consequently, the quality of education the listeners or students received. In the 1980s, a number of such publications had a quite obvious character of atheistic upbringing. Until the end of the 1980s, religion appeared in these texts as an undesirable part of the public life, with which the readers were urged to fight relentlessly.

\section{Related Works}

At present, there is a growing interest in the history of religious science in the USSR, and especially in the question of the place religion took in the Soviet people's life. Relatively recently, St. Petersburg (Smirnov, 2013; Shakhnovich, Chumakova 2014; 2016 etc.) and Moscow (Mitrokhin, 2008; Antonov, Vorontsova, Kolkunova, 2015 etc.) colleagues released great comprehensive publications on this topic. Modern bibliographic and historiographical analysis of texts published in the second half of the $20^{\text {th }}$ century will significantly help to supplement the available information about the specifics of this scientific field development. Publications devoted to the history of religious science development in Siberia repre- sent an important and in its own way unique experience coupled with a variety of regional and cultural specificities and thus are of special interest (Dashkovskii (ed.), 2007-2016; Khomushku, 2005; Dashkovski, 2011).

\section{Book Series Analysis}

In this article, we are going to consider four examples of brochures for teachers and educators united in the Atheist Guide series that was published in the period from 1983 to 1989 by the Omsk publishing house. The series had a recognizable design. The books were small in size $(164 * 130 \mathrm{~mm}$; about 5 printed sheets in volume) and were published in a soft colored paper cover, the style of which symbolized the transition of an enlightened person from the "darkness of religious ignorance" to the "light of atheistic knowledge". The book circulation was very impressive by today's standards: 5,000 copies. The list of authors included CPSU officials, scientists, university professors, representatives of the media, and other educators. The back of the title page of each book in the series contained an abstract with a keynote idea of "overcoming religious ignorance". Bearing the self-explanatory title Atheist Guide, the series can be very interesting for religious theorists, as the material represented within the covers of books is a striking example of educational literature for the scientific atheist workers, at the same time containing interesting facts about the religious life in Omsk and the region.

The first book, Guiding a Person (Zharinov et al., 1983), was published in 1983 and represented a collection of articles written by V.I. Zharinov (Head of Propaganda and Agitation Department of the Regional Committee of the CPSU), Iu.M. Shalaev (Associate Professor of Omsk State University, Candidate of Sciences in Philosophy), L. Shnyreva (Head of Propaganda and Agitation Department of Lubinsk Regional Committee of the CPSU), L. Zhilich (Deputy Editor of the Vechernii Omsk newspaper), A. Guchenkov (Senior Lecturer at Omsk Higher Militia School of the Ministry of Internal Affairs of the USSR, Ph.D), G. Tatarinova (Head of CPSU related department of the Omskaia Pravda newspaper, M. Borovikov (Director of 
the regional Scientific Atheism House). The publication's general tone was embodied in the title of its first article: Atheistic Upbringing Is an Important Task for Communist Party Organizations (Zharinov et al., 1983, 3-13). The author devoted a lot of attention to the history of the Omsk Region and the formation of its multi-confessional throng of believers: "Long before the Great October Socialist Revolution, a large number of Ukrainians, Belarusians, and Germans moved to Western Siberia in search of a better life. The settlers often came in entire religious communities. Kazakhs sought refuge in Russian West Siberian steppes from their feudal lords called bais. In this way, Islam came to be close to the original Orthodoxy, Judaism - to the doctrine of Baptists and some sectarian communities, including Mennonites, Lutherans, Pentecostals, Adventists, etc. This kind of religious diversity has survived in the region to this day. There are eleven religious denominations in its territory" (Zharinov et al., 1983, 3-13). We should also note the conversational language of the narrative, which was rather conversational than popular scientific and thus solved one important task: easy and intelligible presentation allowed to draw into ranks of readers both potential atheistic education activists and all Soviet citizens en mass, that were interested or curious about religious matters. Obviously, these books were not intended to provide a general reader with deep theological knowledge of religious organizations' activity in the territory of the Omsk Region. Instead, they embodied the strategy of the government in relation to religion in general.

As in scientific researches of the 1980s, the first book of the Atheist Guide series fixed the idea that believers were not always anti-social elements, and there were also some known believers among model Soviet citizens: "relative to such people, as it was stressed at the Plenum, our methods should include education, persuasion, and propaganda" (Zharinov et al., 1983, 4). The book also emphasized the necessity of a respectful attitude to a person's feelings and beliefs: "patient, benevolent educational work, involvement in public life, promotion of active attitude to life, filling the labour activity with high social meaning. This is the way of spiritual liberation, restructuring of believers' consciousness, transition to the materialistic worldview position, and getting rid of religious illusions" (Zharinov et al., 1983, 4-5). The author claims that this approach allows achieving more significant results by minimizing conflicts with local residents, encouraging religious organizations to register their activities with the relevant authorities, etc.

The second book in the Atheist Upbringing series (Shalaev, 1986) was published in 1986. The monograph of Iu.M. Shalaev, Candidate of Sciences in Philosophy and Omsk State University professor, consists of two chapters: Real Socialism and Religion and How to Raise a Committed Atheist? It is important that the author concentrates not only on "overcoming religious prejudices" and repeatedly notes that "In atheistic work, we need to pay special attention to people, who have fallen under the influence of religious extremists... We must more actively involve believers in social and political affairs, expand their horizons, deepen their knowledge, and satisfy their 'secular' interests" (Shalaev, 1986, 45). Certain recommendations are offered regarding the content of atheistic upbringing, which should include "critical consideration of religion as a social phenomenon, scientific and materialistic explanation of laws of its origin, evolution, and ways of overcoming, as well as modern activities of religious associations" (Shalaev, 1986, 49). The book abounds in examples of conversations between atheistic lecturers and believers during lectures, as well as successful and unsuccessful answers to certain questions related to religion. It should be noted that Iu.M. Shalaev was actively engaged in scientific and educational work, exploring religions of Omsk and the Omsk Region (Shalaev, 1964, 1970, 1984, 1985 etc.), participating in a number of scientific and practical conferences and editorial boards of several publications, which in one way or another concerned the topic of religion and Soviet people (Sadretdinov (ed.), 1986; Vetoshkin (ed.), 1988). His texts testify to a deep understanding of the life of believers of different faiths in the city of Omsk (Filatov, 2006).

The third book, The Overcoming (Ol'khov, Ianev, 1988), logically continues the 
narrative of the first two books. As we can see from the title, the book urges to "overcome religious prejudices" and to "form a scientific worldview", which is confirmed by the content of chapters What Is a Modern Believer Like?, What Are the Priests Calling For, Do Religious Prejudices Do Harm, etc. A special feature of the publication is frequent references to statistical data of scientific researches on the quantitative and qualitative composition of believers in Omsk and the region, with authors also citing the data of various sociological surveys conducted among the believers. The authors emphasize: "Moreover, these differences ultimately determined by social causes are also influenced by some form of religion, traditions and customs, way of life, historical and local conditions, which can in each case be very different. This once again confirms the need for their careful study" (Ol'khov, Ianev, 1988: 18). The book pays special attention to the opposition between the ritual, ideological positions inherent in the representatives of various religious and Soviet organizations. The priority in all cases is naturally given to the latter. It is important that the book is, on the one hand, a repetition of the main theses presented in the previous books of the series (heterogeneity of the composition of believers, history of the religious expansion in Siberia, the need of collective effort to "overcome religious misconceptions", etc.), while, on the other hand, it prepares the reader for the content of the fourth book, in which the main place would be given to a believer's personality.

The fourth book, The Way to the Heart and Mind (Foigel', 1989), terminates the cycle of narratives about working with believers. This book is a guide to individual work with each believer and clearly shows the scheme of actions for an atheistic educator to undertake in various situations arising in his/her educational work. It is important to note that the main theme of the entire presentation is a respectful, but very persistent, attitude to believers: "Without imposing obvious analogies on a believer, one can make them think about the main question: how does the God of their religion differ from the God of a different religion?" (Foigel', $1989,74)$. In addition to direct "overcoming", a special role is given to securing the achieved result, i.e. creation of 'atheist conviction': "It is very difficult for a person, who has just broken up with religion, to move on to a materialistic understanding of social processes. After all, they are leaping from one level of knowledge to another, and if there is no one to help, such persons will not be able to do it on their own" (Foigel', 1989, 81). The author also mentions the pertaining dangers. Some of them are very curious, like the belief in science: "For example, the idea of science in the service of mankind is beautiful. However, assuming that belief in it on this basis is beautiful too would be wrong, because science requires studying and knowledge, rather than belief. An atheist should tactfully call the attention of a former believer to every misstep of this kind" (Foigel', 1989, 82). The authors note that the ultimate understanding for any atheistic educator is the idea that a believer is, first of all, a Soviet citizen, who requires the same support and development as any other member of the society, who can benefit the common goals. The goal of atheistic upbringing was to organically include believers in the well-functioning mechanism of the Soviet society.

\section{Conclusion}

The Atheist Guide series is a complete supporting package of materials for the atheistic upbringing that, according to the authors, included four levels for a student: 1) awareness of religion as an undesirable component in the Soviet people's life; 2) balancing the world outlook priorities in accordance with atheistic propaganda; 3 ) overcoming religious prejudices through the involvement of believers in activities of the Soviet society; 4) replacing the religious component with the atheist. The four small books contain the whole atheistic upbringing system based on actual knowledge about features of religious life in Omsk and the region. The authors of the series consider religion as a naturally developing phenomenon that evolves under various factors of people's daily life and changes depending on the social and political environment. While scholars in their researches increasingly revealed the failure of the idea of the com- 
plete overcoming of religious views through the results of scientific achievements (Kapustin, 1984; Elenskii, 1989; Mitrokhin, 1973 et al.), the authors of the considered books did not demonstrate such views (here, we need to take into account the nature and the target audience of publications). At the same time, the authors of the series still perceived religious faith as a lack of education on the part of citizens, which required methodical educational interventions. A large number of scientific and statistical materials significantly enriched the content of these books, and their specific language made the texts accessible (primarily in their meaning) to a wide range of educators and students.

As a result, the book series views religion as a complex social phenomenon dependent upon a number of historical and regional features, having its own causes of origin and development, and in general playing an important role in the life of Soviet people.

\section{References}

Antonov, K.M., Vorontsova, E.V., Kolkunova, K.A. (2015). "Nauka o religii”, "Nauchnyi ateizm”, "Religiovedenie": aktual'nye problemy nauchnogo izucheniia religii v Rossii XX - nachala XXI v. ["Science of Religion", "Scientific Atheism”, "Religious Studies”: Actual Problems of the Scientific Study of Religion in Russia of the XX-Beginning of the XXI Century]. 2-nd ed. Moscow, Orthodox St. Tikhon Humanitarian University, 263 p.

Dashkovskii, P.K. (ed.) (2007-2016). Mirovozzrenie naseleniia Iuzhnoi Sibiri i Tsentral'noi Azii v istoricheskoi retrospective [The Worldview of the Population of Southern Siberia and Central Asia in Historical Retrospective]. Barnaul, Azbuka.

Dashkovskii, P.K. (2011). Mirovozzrenie kochevnikov Saiano-Altaia i sopredel'nykh territorii pozdnei drevnosti i rannego srednevekov'ia (otechestvennaia istoriografiia i sovremennye issledovaniia) [The Worldview of the Nomads of the Sayan-Altai and Adjacent Territories of Late Antiquity and the Early Middle Ages (Russian Historiography and Modern Research)]. Barnaul, Altai State University, 243 p.

Elenskii, V.E. (1989). Protestantskoe sektantstvo v sovetskom obshchestve: analiz adaptivnykh protsessov [Protestant Sectarianism in Soviet Society: an Analysis of Adaptive Processes]. Kiev, 17 p.

Filatov, V.I. (2006). O kafedre filosofii [On the Department of Philosophy]. In Ocherki istorii Omskogo gosudarstvennogo universiteta v vospominaniiakh, dokumentakh, litsakh [Essays on the History of Omsk State University in Memoirs, Documents, Faces]. Omsk, 131-132.

Filist, G.M. (1986). Urbanizatsiia i sektantstvo [Urbanization and Sectarianism]. Minsk, 126, [2] p.

Foigel', A.M. (1989). Put' k serdtsu i razumu [Way to Heart and Reason]. Omsk, Omsk Book Publishing House, 110, [2] p.

Kapustin, N.S. (1984). Osobennosti evoliutsii religii: na materialakh drevnikh verovanii $i$ khristianstva [Features of the Evolution of Religion: on the Materials of Ancient Beliefs and Christianity]. Moscow, $222 \mathrm{p}$.

Khomushku, O.M. (2005). Religiia v kul'ture narodov Saiano-Altaia [Religion in the Culture of the Peoples of Sayano-Altai]. Moscow, Russian Academy of Public Administration under the President of the Russian Federation, 227 p.

Mitrokhin, L.N. (1973). Khristianstvo v epokhu nauchno-tekhnicheskoi revoliutsii. Stat'i 1-3 [Christianity in the Era of the Scientific and Technological Revolution. Articles 1 to 3]. In Nauka i religiia [Science and Religion], 6, 28-34; 8, 9-14; 11, 29-35.

Mitrokhin, L.N. (2008). Filosofskie problemy religiovedeniia [Philosophical Problems of Religious Studies]. St. Petersburg, Russian Christian Academy of Humanities, 1046 p.

Ol'khov, O.P., Ianev, I.G. (1988). Preodolenie [Overcoming]. Omsk, Omsk Book Publishing House, 109, [3] p.

Sadretdinov, G.K. (ed.) (1986). Problemy ideino-politicheskoi bor'by v stranakh Zapadnoi Evropy $v$ novoe i noveishee vremia [Problems of the Ideological and Political Struggle in Western Europe in Modern and Recent Times]. Omsk, Omsk State University, 100 p. 
Shakhnovich, M.M., Chumakova, T.V. (2014). Muzei istorii religii Akademii nauk SSSR i rossiiskoe religiovedenie (1932-1961) [The Museum of the History of Religion of the USSR Academy of Sciences and Russian Religious Studies (1932-1961)]. St. Petersburg, Nauka, 458 p.

Shakhnovich, M.M., Chumakova, T.V. (2016). Ideologiia i nauka: izuchenie religii v epokhu kul'turnoi revoliutsii v SSSR [Ideology and Science: the Study of Religion in the Era of the Cultural Revolution in the USSR]. St. Petersburg, Nauka, $367 \mathrm{p}$.

Shalaev, Y.M. (1964). Sovremennoe pravoslavie i nauka. O bogoslovskikh popytkakh primireniia religii i nauki [Modern Orthodoxy and Science. On Theological Attempts to Reconcile Religion and Science]. Moscow, Mysl', 87 p.

Shalaev, Y.M. (1970). Osobennosti sovremennogo etapa bor'by nauki i religii [Features of the Modern Stage in the Struggle of Science and Religion]. Omsk, 29 p. March.

Shalaev, Y.M. (1984). Ekzamen na zrelost' [Maturity exam]. In Sovetskaia Rossiia [Soviet Russia], 21

Shalaev, Y.M. (1985). Rol' predmeta "Osnovy nauchnogo ateizma" $v$ formirovanii nauchno-ateisticheskogo mirovozzreniia studencheskoi molodezhi [The Role of the Subject "Fundamentals of Scientific Atheism" in the formation of the Students' Scientific and Atheistic Worldview]. In Aktual'nye voprosy teorii i praktiki kommunisticheskogo vospitaniia studencheskoi molodezhi. Tezisy dokladov i nauchnykh soobshchenii oblastnoi nauchno-prakticheskoi konferentsii [Actual Issues of the Theory and Practice of Communist Education of Student Youth. Abstracts of Reports and Scientific Reports of the Regional Scientific and Practical Conference]. Omsk, 81-84.

Shalaev, Y.M. (1986). Vospitat' ateista [To Raise an Atheist]. Omsk, Omsk Book Publishing House, $108,[4] \mathrm{p}$.

Smirnov, M.Y. (2013). Religiia i religiovedenie v Rossii [Religion and Religious Studies in Russia]. St. Petersburg, $365 \mathrm{p}$.

Vetoshkin, A.P. (ed.) (1988). Chelovecheskii faktor v mekhanizme uskoreniia obshchestvennogo progressa: vospitanie i obrazovanie: Tezisy dokladov nauchnoi konferentsii "Chelovecheskii faktor v mekhanizme uskoreniia obshchestvennogo progressa: problemy formirovaniia aktivizatsii" [The Human Factor in the Mechanism of Accelerating Social Progress: Upbringing and Education. Abstracts of the Scientific Conference "The Human Factor in the Mechanism of Accelerating Social Progress: the Problems of the Formation of Activation"]. Omsk, Omsk State University, 229 p.

Zharinov, V.I., Shalaev, Y.M., Shnyreva, L., Zhilich, L., Guchenkov, A., Tatarinova, G., Borovikov, M. (1983). Pomoch' cheloveku [To Help a Person]. Omsk, Omsk Book Publishing House, 68, [4] p. 


\title{
Книга как элемент атеистической воспитательной работы на примере серии «В помощь атеисту»
}

\author{
М.В. Колмакова \\ Институт философии человека \\ Российский государственный педагогический \\ университет им. А.И. Гериена \\ Российская Федерачия, Санкт-Петербург
}

\begin{abstract}
Аннотация. Статья посвящена серии книг «В помощь атеисту», опубликованных в период с 1983 по 1989 год в Омском книжном издательстве. Книги содержат четко разработанную атеистическую воспитательную систему, учитывающую особенности религиозной жизни г. Омска и области. Материал, заключенный в книгах, может быть интересен религиоведам и историкам в качестве вспомогательного комплекса сведений об атеистическом воспитании в Сибири. Авторы серии рассматривают религию в качестве закономерно развивающегося социального явления, эволюционирующего в соответствии с различными факторами, но в то же время религия в этих текстах является одной из форм проявления низкого уровня образованности граждан. В целом, книги серии призывают не только «преодолевать религиозные заблуждения», но воспринимать религию как феномен играющий важную роль в жизни советских людей.
\end{abstract}

Ключевые слова: научный атеизм, наука о религии, СССР, Омск, книжная серия.

Исследование выполнено при финансовой поддержке РФФИ в рамках научного проекта № 19-311-60008.

Научная специальность: 09.00.14 - философия религии и религиоведение. Искусствоведение и культурология. 